\title{
Conflict Within the ICFTU: Anti-Communism and Anti-Colonialism in the 1950s
}

\author{
ANTHONY CAREW
}

Summary: Formed as an anti-communist labour international, the International Confederation of Free Trade Unions (ICFTU) nevertheless experienced internal conflict over the appropriate approach to communism. The different perspectives of the two largest affiliates, the British TUC and the American AFL-CIO, caused disharmony and ultimately near organizational paralysis until it forced a change of leadership. Caught between these rival positions, the ICFTU secretariat's relations with the AFL-CIO were initially the most strained, but as the International extended its activity in Africa, in a bid to outflank communist organization among labour, relations with the TUC also deteriorated over the correct stance on nationalism and colonialism.

\section{Introduction}

Though fundamental to the project of the labour movement, internationalism among trade unions has always been the most difficult dimension of solidarity to sustain. Intermittent successes at this level have served as inspiration for successive generations of trade unionists to demonstrate once more that what animates the movement is the international ideal of brotherhood, indeed nothing less than the call to build a new world. Yet such idealism has proved hard to translate into concrete achievement. The trade union movement's natural opponents have never lacked strength and influence on the global stage, but labour's relatively disadvantaged position has also been compounded by divisions within their own ranks. Consequently, it is important to study this aspect of trade unionism if we are to assess the prospects for a viable internationalism in the future.

From the end of the nineteenth century permanent international structures began to take shape in the various trade secretariats created by unions in specific industries. National trade union centres were linked together from 1903 by the International Secretariat of Trade Union Centres (ISTUC) which was superseded in 1919 by the International Federation of Trade Unions (IFTU). Throughout the inter-war years the IFTU failed to establish a real presence beyond Europe. It was sniped at by the Comintern's Red International of Labour Unions (RILU) and

International Review of Social History 41 (1996), pp. 147-181 
large American labour movement. However, in the course of World War II international cooperation among the trade union centres of the allied nations aroused hopes for the creation of an all-embracing labour federation in the post-war world that would overcome the previous divisions. The subsequent formation of the World Federation of Trade Unions (WFTU) in 1945 thus represented an ambitious attempt to sustain in peacetime the spirit of solidarity forged in the allied war effort, especially between the WFTU's three most influential affiliates, the British Trades Union Congress (TUC), the All Union Central Council of Trade Unions (AUCCTU) of the Soviet Union and the American Congress of Industrial Organizations (CIO). It proved to be a short-lived experiment. Tensions caused by the developing cold war, into which the labour movement was inevitably drawn, and mutual suspicions harboured by communist and non-communist trade unionists since their days of bitter opposition in the 1920s and 1930s began to cripple the WFTU. At the same time, vehement hostility to it on the part of the longerestablished wing of the American labour movement, the American Federation of Labour (AFL), and its claims that the WFTU was communist dominated helped galvanize a growing opposition to the world body and in 1949 forced a split. Most of the "Western" trade union centres now withdrew their support and founded an explicitly anti-communist international - the International Confederation of Free Trade Unions (ICFTU).

With the growing internationalisation of capital, there has never been a time when international coordination within the labour movement was more essential than now. That recognition has generated a resurgence of interest in past attempts at building labour internationalism. British and continental historians are now re-examining the development of the international trade secretariats. ${ }^{1}$ The predecessor organizations of the ICFTU have also been the focus of renewed historical interest. ${ }^{2}$ Focusing

' See, for example, the examination of the International Transport Workers Federation in S. Koch-Baumgarten, "Geschichte der Internationalen Transportarbeiterfoderation 1896-1993: Ein gewerkschaftlich-wissenschaftliches Kooperationsprojekt", Internationale Wissenschaftliche Korrespondenz zur Geschichre der deutschen Arbeiterbewegung (June 1994) and Bob Reinalda (ed.), The Fimmen Years 1917-45: Contributions to the ITF Inter-War History (fortheoming, 1996).

2 The shortcomings of the International Secretariat of Trade Union Centres have been explored in S. Milner, "The International Labour Movement and the Limits of Internationalism: the International Secretariat of the National Trade Union Centres 1901-1913", International Review of Social History, 33, 1 (1988). The internal problems besetting the IFTU initially chronicled by L. Lorwin. The International Labour Mtovement (New York, 1953) are currently being reappraised by Geert Van Goethem in a forthcoming study conducted under the aegis of the IISH. The fissures in the WFTU that ultimately led to the schism of 1949 have been the subject of historical analysis by P. Weiler, "The United States, International Labour and the Cold War: The Break-up of the World Federation of Trade Unions", Diplomatic History, 5, 1 (Winter 1981); A. Carew, "The Schism Within the World Federation of Trade Unions Government and Trade Union Diplomacy". 
on the ICFTU and based on recently released documentation in the archives of the ICFTU, the AFL-CIO and the TUC, the present article sets out to identify and analyse the internal causes of conflict within the Confederation that hampered its effectiveness during its first decade and cast doubt on the very possibility of meaningful international trade union cooperation, even among labour organizations that found themselves on the same side of the communist/non-communist divide at the height of the cold war. ${ }^{3}$

\section{The ICFTU as battleground}

Formed in December 1949 and operational from February 1950, the International Confederation of Free Trade Unions existed to foster links between national trade union centres, to represent labour before inter-governmental agencies and to nurture trade unionism in newly industrializing countries. It was created following the schism in the World Federation of Trade Unions which, from 1945 to 1949 , had united the majority of the world's national labour centres. The WFTU split saw the majority of Western labour centres desert the Federation as a result of tensions generated by the introduction of Marshall Aid, tensions that revealed deep-rooted differences in style and purpose between communist-led and non-communist movements.

Although 108 national centres belonged to the ICFTU in the mid-1950s it was the British and American affiliates who tended to dominate in the Confederation's debates and whose outlook defined the parameters

Intermational Review of Social History, 24, 3 (1984) and D. McShane, International Labour and the Origins of the Cold War (Oxford, 1992).

${ }^{3}$ The early development of the ICFTU has been chronicled by John Windmuller, American Labour and the International Labour Movement 1940-53 (Ithaca, 1954). A series of articles by Windmuller, often reporting on the ICFTU congress, updated periodically this initial account "The Stockholm Congress of the ICFTU", Industrial and Labour Relations Review, 7, 3 (April 1954); "The Vienna ICFTU Congress", Industrial and Labour Relations Review, 9, 2 (1956); "ICFTU After Ten Years: Problems and Prospects", Industrial and Labour Relations Review, 14, 2 (January 1961); "Leadership and Administration in the ICFTU: A New Phase of Development", British Journal of Industrial Relations, 2 (June 1963); "Cohesion and Disunity in the ICFTU: The 1965 Amsterdam Congress", Industrial and Labour Relations Review, 17, 3 (April 1966); "Internationalism in Eclipse: The ICFTU After Two Decades", Industrial and Labour Relations Review, 23, 4 (July 1970) and "Realignment in the ICFTU: The Impact of Detente", British Journal of Industrial Relations, 14, 3 (1976). The major sources for the present article are the Presidential Papers of AFL-CIO President, George Meany, International Files Series 9 (hereafter "Meany Collection") located at the George Meany Archives, Silver Spring, Maryland; Archives of the Trades Union Congress, Modern Record Centre, Warwick University, Coventry; Archives of the ICFTU, International Institute of Social History, Amsterdam; UK Ministry of Labour Papers (Series 13), Public Record Office, Kew; United Automobile Workers (UAW), International Department Collection (Reuther-Carliner 1956-1962) and Victor Reuther Collection, Walter Reuther Archives, Detroit; Archives of the Canadian Labour Congress (CLC), National Archives of Canada, Ottawa. 
of its organizing activity. The British and American labour movements were by far the largest and most powerful components of the International in the 1950s, and their frequent inability to work together constructively in that decade considerably reduced the ICFTU's influence as a force for international trade unionism. How much more successful the ICFTU might have been given greater harmony between the two labour movements can only be guessed at and would require an assessment of the wider constraints on international labour solidarity. But, without doubt, Anglo-American animosity within the ICFTU produced something close to organizational paralysis by 1960 , a stalemate that lingered and was only resolved (to the advantage of neither party) when the Americans withdrew from the International in 1969.

The lack of harmony between these two national groups was a product of ideological differences exacerbated by sharp clashes of personality. At its foundation the ICFTU's ideological stance was significantly infiuenced by the American Federation of Labour which had been the WFTU's staunchest opponent. From the outset the International had a specific anti-communist (or "free" trade union) focus which lent a particular gloss to the objective of fostering labour solidarity. For the most zealous anti-communists in the AFL, the overriding purpose was to build an international labour movement that would form a bulwark against the spread of communism and even become an aggressive opponent, encroaching in areas controlled by communists in order to lay the foundation for their emancipation. ${ }^{4}$ For other affiliates, like the British Trades Union Congress, anti-communism was less of an ideological crusade and, though the rhetoric was similar, the belief was that the best way to counter communism's appeal for the oppressed was to help build effective trade unionism and with it the mechanism for workers to negotiate their own improved living conditions. Domestically the TUC had long since developed a modus vivendi with British communists, and likewise in the international field were apt to tolerate piecemeal compromises with their ideological opponents. Differences of emphasis such as these would be central to the tension that ran through the ICFTU during the 1950s.

While Anglo-American rivalry was at the heart of internal ICFTU disagreement there were in fact four key players whose moves and counter-moves constituted a quadrille rather than a minuet. As important as the cleavage between the AFL and the TUC were philosophical differences between the AFL and the American labour movement's industrial wing, the Congress of Industrial Organizations, which from 1955 became the AFL's uneasy partner in the merged American

4 The AFL had wanted the ICFIU to create a department for trade unionist refugees from the Soviet bloc which would be responsible for organizing infiltration of the Soviet satellites. American Federationist (July 1949), pp. 6-8. 
Federation of Labour-Congress of Industrial Organizations (AFL-CIO). In many respects the TUC and the CIO had much in common and their leaders, often sharing a formative experience in democratic socialism, were more at one with each other than either was with their AFL counterparts. But their closeness was also a source of friction within the American labour movement: the AFL believed that the TUC played off one section of the US labour movement against the other for their own advantage, and as long as the CIO leadership had close ties to the TUC they were suspect in AFL eyes.

The fourth party in this matrix was the secretariat of the ICFTU, led by its Dutch general secretary, J.H. Oldenbroek. A man of great experience in the international field, he had been an ally of the AFL in breaking up the WFTU and in 1949 was the American choice for general secretary of the new International. But the AFL leadership soon came to mistrust him, seeing him as a typical European socialist labour leader, moulded by his experience of the inter-war international labour movement and unable to break with the Eurocentric values of the International Federation of Trade Unions (IFTU) which had preceded the WFTU. Most importantly they considered him to be effectively under the thumb of the TUC's general secretary, Sir Vincent Tewson. Indeed Oldenbroek and Tewson were close and shared a common perspective on trade unionism as a pragmatic adjunct to social democratic politics. The Brussels-based secretariat that Oldenbroek headed was a mixture of nationalities, but only two out of 64 staff were American while 15 were British including three out of nine chiefs of staff. Not only were Americans few in number in the secretariat but problems of travel meant that American representation at meetings of the Executive Board and its sub-committees in Brussels was often left to junior representatives of their international staff. Frustrated by their difficulty in exerting day-to-day influence in Brussels, AFL criticisms of the secretariat were twofold: that it was riddled with socialists whose reliability in the cold war was suspect, and that at best administration of programmes by ICFTU bureaucrats was ponderous and unimaginative. Occasionally seen as saboteurs, more frequently as incompetents, the members of the secretariat became the object of deep mistrust by the AFL.

\section{Independent activities}

In founding the ICFTU the intention was that, operating through regional structures, it would take the lead in international policy and that affiliated national centres would loyally assist its execution of agreed programmes. In Europe those programmes would focus on the politics of post-war economic reconstruction, with the ICFTU cooperating in the work of the Marshall Plan. In other continents, the main task would be to transform embryonic trade union movements into cohesive national 
centres affiliated to the Confederation or, where unionism was absent, to help nurture it at the grass roots. In practice such a project, led from ICFTU headquarters and with affiliates contributing as and when possible, was never achieved. Indeed by the end of the decade it came to be seen as an impossible objective. Independent international programmes and activities conducted by national centres in parallel with, or in opposition to, the work of the ICFTU were a fundamental source of friction.

Since 1944 the AFL had operated independently overseas, its policy programme conducted by the Free Trade Union Committee (FTUC), a voluntary organization subscribed to by a number of AFL affiliates but not wholly integrated into the AFL structure. After the war the FTUC operated in parallel with the AFL's official International Labour Relations Committee without any clear jurisdictional boundary between them. Headed by Jay Lovestone, former secretary of the Communist Party (USA) but now fiercely anti-Stalinist, the FTUC was a major influence in the world of international labour during the 1950s and, because of its semi-official nature, a highly controversial one. Despite the existence of an International staff in the AFL under the direction of the International Labour Relations Committee, the FTUC was always the dominant force in international policy, with Lovestone having ready access to George Meany, the AFL Secretary-Treasurer until 1952 and subsequently President. Lovestone had a network of agents and reporters abroad, some, such as his lieutenant Irving Brown, on the AFL payroll, others not. Though concrete proof is only just emerging, the FTUC-AFL provided a convenient cover for activities funded by the intelligence services from the end of 1948. More generally, independent labour activities were often a component of government aid programmes, activities such as training labour leaders being supervised by American labour with government funding. ${ }^{5}$

The AFL's strident anti-communism was a reflection of FTUC influence, its opposition to the communist bloc often outpacing that of the US government itself. Labour's policies and programmes flowed from analyses based on this body's central preoccupation. The tension between the AFL, on the one hand, and the TUC and the CIO on the other, had much to do with the curious role of this unofficial and largely unaccountable body at the centre of AFL international policy-making. The TUC mistrusted FTUC operatives as practitioners of communism in reverse, and it was commonplace for the TUC and their friends in the CIO to denounce what they termed the AFL's "negative anti-communism".

"On CIA funding of the Free Trade Union Commiltee see A. Carew, "The LovestoneBrown Connection: Labour's Covert Operations", forthcoming. US government-funded training of foreign labour leaders was a particular feature of the Marshall Plan. See the author's Labour Under the Marshall Plan: The Politics of Productivity and the Marketing of Management Science (Manchester, 1987). 
However, independent international activities were also a prominent feature of the TUC programme. Since the 1930s the British labour movement had presided over the development of trade unions on the British model in its colonies. Colonial administrations employed labour officers appointed on the recommendation of the TUC. Though civil servants, they were part of the process through which the British labour movement maintained its influence abroad. In the 1950 s, while posing as a loyal affiliate of the ICFTU, the TUC jealously protected its own interests in commonwealth and former commonwealth territories. It accepted an ICFTU role there as long as the International played the game by British rules and without undermining Britain's interests, but when these were challenged it, no less than the AFL and the FTUC, was prepared to defy the ICFTU. International labour action conducted exclusively through the ICFTU was, then, the aim of purists, while independent activity by national centres was often the reality of trade union internationalism.

Generally American and British labour leaders worked closely in international affairs with their own government, sharing broad perspectives. The development of labour policy allowed for considerable input from government foreign policy professionals whose contacts, formal and informal, with the labour centres were extensive. The TUC was represented on the Colonial Office's Colonial Labour Advisory Committee, American unions held seats on the federal Aid Agency's Labour Advisory Board, and in both countries the trade union leaderships maintained close links with labour attachés who sometimes served as informal sources of intelligence and advice for the unions.

In all of this, the legacy of past skirmishes, personality clashes and cultural differences added to the philosophical divisions. Personal animosity was most noticeable in the disputes over "Lovestoneism". Jay Lovestone had figured prominently in 1930s factionalism between the AFL and the $\mathrm{CIO}$ where he had been employed to counter the influence of communists and had crossed swords with autoworkers leader Walter Reuther who became president of the $\mathrm{CIO}$ in 1952. Likewise, Irving Brown had been a Lovestoneite in the struggle for control of the fledgling United Auto Workers in the 1930s, and after the war, first as the FTUC's man in Europe and later as European representative of the AFL, he had developed a bitter personal rivalry with Victor Reuther, head of the CIO's Marshall Plan programme in Paris. Mutual hostilities rooted in the 1930s American labour movement were of no small significance in the field of international labour in the 1950s.

Differences between leading figures on the British and American sides also had a powerful negative influence. While sharing the AFL leadership's detestation of communism, the TUC's Arthur Deakin had little time for their international intrigue, a position that appears to have stemmed from the time in the late 1940s when, as president of the WFTU, he was attempting to steer it along the ideological straight and narrow while the 
FTUC was bent on destroying the organization. Where the TUC leadership saw American brashness, lack of sophistication and inexperience in the wider world of international diplomacy, the AFL in particular bridled at the sense of superiority exuded by the TUC while criticizing what it regarded as the cautious conservatism of the British trade union bureaucracy with its lack of dynamism and drive. While privately Oldenbroek and Tewson might patronize the Americans for their superficial and unrealistic approach to international issues, based, they argued, on no real continuous knowledge or understanding of the countries in which they interfered, the Lovestone circle derided the corruption of the TUC's "socialist" leadership by the British honours system - "the Knights of the Round Table" was the scornful label given to TUC worthies such as Sir William Lawther, Sir Lincoln Evans, Sir Tom Williamson, Sir Tom O'Brien, Sir Alf Roberts, all led by the "pompous clerk", Sir Vincent Tewson. Other perceived opponents such as Walter Reuther and J.H. Oldenbroek were sometimes accorded honorary membership of this group, derisively transformed into "Sir Walter Reuther" and, for allegedly being in Tewson's pocket, "Sir Vincent Oldenbroek". Mockery and vituperation were commonplace: in FTUC circles the deeply mistrusted Oldenbroek was commonly referred to as "Mona Lisa" for his enigmatic smile, while a variety of officials in the Brussels secretariat or the TUC would be dismissed as either "British stooges" or "stooges of the Foreign Office". The bitterness of the language used in private was a fair reflection of the gulf between many of the key actors.

Throughout the decade the debate and disagreements between the ICFTU's principal affiliates took place in the context of landmark events in the cold war - the Korean War; the death of Stalin; the Berlin uprising; the four-power Geneva summit; the emergence of Krushchev and his secret speech to the 20th party congress; the Polish and Hungarian uprisings; the Suez crisis and the growth of Pan-Africanism. The International's response (or non-response) to these would generate internal conflicts, sometimes prompting further disputes on matters of ICFTU organization and structure. A continuous state of mistrust and mutual wariness was punctuated by periodic crises, sometimes resolved on a temporary basis by informal deals struck outside the official ICFTU structure.

There was a certain predictability about the cycle of ICFTU debate. The Americans, with their large delegation and combative style would often dominate at the biennial congresses and establish an agenda consistent with their interpretation of the International's true purpose. The development and implementation of that programme would then be a matter for the half-yearly meeting of the Executive Board (and intervening Emergency Committee meetings) aided by the secretariat where the TUC, its North European allies and Oldenbroek would often drag their feet or apply their own gloss and so incur American resentment. During the first 
half of the 1950s the ostensible conflict was between the AFL and the ICFTU. In the final years of the decade the International's miscreants were increasingly the TUC. By the end of the decade both national centres had their own distinct grievances with the ICFTU leadership and this resulted in a vain attempt to resolve the problem by means of a wholesale replacement of the International's top officials.

\section{Initial disagreements}

The first eighteen months of the ICFTU's existence were low key, spent building up an organization from scratch. From the very outset, though, there were indications that the AFL would not be content to work exclusively through the International but would retain the capacity to act independently if necessary. In operation for only four months when the Korean War broke out, the ICFTU's response to the start of hostilities was muted and AFL irritation was clear. Complaining at the lack of anti-communist publicity Irving Brown wrote:

Unless we can show more desire on the part of the ICFTU to play a role in these hot issues, the reason for the existence of the ICFTU becomes less and less. ${ }^{6}$

Nevertheless, a "wait and see" policy prevailed until the second congress at Milan in July 1951 when the first significant disagreement surfaced. Contrary to an unwritten agreement that the ICFTU would avoid big power domination of its structures, Vincent Tewson was elected president at the congress. The AFL objected and refused to make the choice unanimous. Even so they were still prepared to work through the International and planned to contribute to the newly established Regional Activities Fund (RAF) through which the International's organizing work in developing countries would be financed.

However, at the first Executive Board meeting presided over by Tewson in November 1951 a series of decisions went against the AFL a vote not to accept the application for affiliation of the anti-communist Australian Workers Union (AWU); in favour of the affiliation of the Italian federation, UIL, without first requiring it to merge with the AFL's own favoured anti-communist Italian federation, CISL, which was already affiliated, and most important of all the president's ruling out of order a motion by Meany which denounced the absence of free trade unions in Yugoslavia. In the development of AFL-ICFTU-TUC relations this was the crucial moment. It was not just the decisions themselves but the manner in which they were taken that outraged Meany. He complained that Tewson had bent the International's rules of procedure and that Oldenbroek had aided him by misleading the congress about

- Brown to Meany, 16 August 1950. Meany Collection, Box 57 (21). 
whether the AWU had officially applied for affiliation. Oldenbroek was accused of "lying" and "playing the British game", and Tewson was accused of "bureaucratic manoeuvring". The AFL complained of "factional trickery" while "stooges" were relied on to carry the votes."

Meany now refused to contribute to the Regional Activities Fund, applying a financial tourniquet to the International that would be a recurrent tactic throughout the 1950s. He had read the signs as indicating that the International was soft on communism, and for the next twelve months the AFL boycotted Executive Board meetings while the possible implications of the the AFL leaving the Confederation were discussed in FTUC circles. A war of words broke out between the AFL and the TUC, Meany's criticism of the ICFTU in the American press prompting Arthur Deakin to berate Meany for airing his grievances in public. That Deakin should adopt such a pose was, in Lovestone's estimation, an indication of how far Bevanite ideas on internationalism had permeated beyond the British left. ${ }^{8}$ In fact Deakin was the most bitter and unrelenting opponent of Bevanism. Nor was there throughout the 1950s the faintest echo of Bevanism in the foreign policy positions adopted by the TUC. That confusion existed in American minds on this issue was a clear indication of the problems of communication between the two centres.

In these matters the TUC preference was always for quiet diplomacy. Some of its leaders were willing to accept that the AFL's personal criticisms of Oldenbroek and Tewson had foundation, and the TUC general secretary was persuaded by his colleagues to go to the USA to try to mend fences. Eventually the boycott of the Executive Board (though not the Regional Activities Fund) ended in December 1952, but not before the AFL published a statement criticizing the ICFTU leadership for "lacking alertness, initiative and the sense of urgency demanded in the deepening world crisis" and urging the International to become "the foremost champion of the peoples fighting for their national independence" in the Near and Middle East even if it meant "opposition to certain policies of the governments of free countries".? This was the first clear sign that the AFL was willing to challenge the International's European affiliates over their governments' colonial role.

Irving Brown, who had been unhappy with the boycott tactic, believed that the AFL's best approach was to be active within the ICFTU so as to prevent any further concessions to communism by a European labour movement which he believed was a prisoner of past clichés and was now "entering more and more into a period of appeasement and

7 Brown to Lovestone, 2 December 1951, ILGWU Archives, Box 261 (6a), Catherwood Library, Cornell University, Ithaca, NY.

- Lovestone to Meany, 1 April 1952, Meany Collection, Box 57 (22).

- Green to ICFTU Affiliates, 2 May 1952, CLC Collection, vol. 257. 
pseudo-radicalism". He urged AFL president George Meany of the need for careful scrutiny of the International's secretariat whose socialist inclinations, he thought, might be reinforced as a consequence of the recent re-establishment of the Socialist International. At the same time he advocated supplementing the American role within the International through a vigorous independent programme, a two-pronged approach reflecting "the special role of the American trade unions in the world today". 10

The ICFTU and anti-communism: 1953-1957

The signs of a slight thaw in East-West relations that followed Stalin's death in 1953 put the AFL on the alert. For Irving Brown, Winston Churchill's May 1953 proposal for a big power summit "crystallised all the neutralist and defeatist thinking which has characterised Europe for some time". Anticipating that British and European labour movements would be slow to respond to this development, he advocated that the Americans seize the initiative:

We have got to stress the fundamental nature and structure of the Soviet Society which is in existence and which determines in large measure the kind of policies being pursued by the new regime [.. . ] we have a great opportunity to launch a political offensive to prevent their stabilisation and the creation of a new dictator."

The suppression of the Berlin uprising the following month and the ICFTU's slow reaction gave the AFL the opportunity to lead labour movement denunciations. The events in Berlin preceded by a month the International's Stockholm Congress where AFL delegates seized the high moral ground. As president, Tewson spoke cautiously about the potential for East-West understanding, warning against "any sabotage, whether by word or deed, that may wreck the possibility of negotiations". For the FTUC this was "vile appeasement" and as Meany told the delegates: "No dictator in history has ever been converted to a policy of reason or human decency by appeasement. This is no time for backsliding under the pretext of caution."12

At Stockholm Tewson was replaced as president by the Belgian Omer Becu who, like Oldenbroek, had a wartime background in American intelligence where he worked with the OSS. ${ }^{13}$ It was a victory for the

${ }^{10}$ Brown to Meany, 21 October 1952, Meany Collection, Box 57 (21).

"Report from Irving Brown, 23 May 1953, Meany Collection, Box 56 (2).

12 Message from Lovestone to Dubinsky, 7 July 1953, ILGWU Archives, Box 261 (6a); Proceedings, ICFTU Congress, July 1953, p. 208.

13 Omer Becu had been a leader of the Belgian Seamen's Officers Union. In the course of his career he suoceeded Oldenbroek twice, first as general secretary of the International Transport Workers' Federation in 1950 and secondly as ICFTU general secretary in 1960. Initially a close associate of Oldenbroek, he became critical of him during the years 19511957 when he was the president and Oldenbroek the general secretary of the Confederation. 
AFL who had backed Becu and had secured support for a change in the constitution to allow the presidency to go to someone outside the Executive Board. With the Americans in the ascendant - winning support for the creation of a permanent committee to gather information on "slave labour" practices in the USSR - the TUC maintained a low profile in the interests of preserving ICFTU stability. But in debate Charles Geddes of the TUC complained about AFL triumphalism:

when we reach understandings [...]. there is nothing quite so bitter as the shouts of victory in the ears of those who are supposed to have been defeated. ${ }^{14}$

The outcome of the Stockholm Congress was the emergence of two blocs within the International, a European bloc led by the TUC, reflecting in the eyes of the British labour attache an "orthodox and moderating influence" and a bloc led by the AFL and including a growing number of centres from developing countries which would be "more susceptible to disturbance". American support for independence movements was expected to grow and, as the attaché remarked: "we may expect to see their finger frequently in our commonwealth and colonial pies". ${ }^{15}$

However, in characteristic fashion the advances made in the heat of the congress proved difficult to sustain in the longer term. The AFL had won support for the establishment of a "Berlin Committee" to dispense funds to dissident worker groups in Eastern Europe and to engage in underground activities. ${ }^{16}$ The work of the committee was entrusted to the German trade union centre DGB and, unlike the AFL, the TUC were happy to regard the activity as a German affair. On this point Deakin had clashed with Irving Brown, in the process describing the latter's attitude to the WFTU as "McCarthyite"." But the AFL became concerned at the lack of adventure on the part of the DGB who were thought to be anxious not to upset the Soviet authorities in the Eastern zone. For reasons of security there was little reporting back by the committee and, concerned about the possibility of backsliding, the AFL insisted on having a seat on it. For the DGB it was a sign of lack of trust which was much resented. They complained that AFL interest in the operation went beyond pure trade union activities and involved "politics". The AFL were also aggrieved when in summer 1954 ICFTU affiliates broke ranks during the ILO Conference and failed to

Like Oldenbroek, Becu was originally the Americans' preferred choice for 1CFTU general secretary but, also like Oldenbroek, he later lost Meany's confidence. His health broke under the pressure of work in the ICFTU and he retired early in 1967.

${ }^{14}$ AFE Convention Proceedings, 1953, p. 59.

is Report on the Stockholm Conference of the ICFIU of July 1953, Labour Attache (Brussels), 15 July 1953, UK Ministry of Labour Papers, LAB 13996.

${ }^{16}$ This was, in effect, an attempt to swing the ICFTU behind a covert project that the AFL had been engaged in through the FTUC with CIA funding since 1950.

17 The truth was that Brown and Lovestone were no more admirers of Senator MeCarthy than Deakin was of Bevan. 
vote as a block against the admission of the USSR to the International Labour Organization in line with the International's policy. Again the TUC were among the defaulters. ${ }^{18}$

In other respects the two years following the Stockholm Congress saw no dramatic ICFTU successes. Their organizing efforts were unspectacular. There was modest progress in Africa, no major achievement in Latin America, and a failure to secure the prize affiliation of the principal Japanese trade union centre. Discussion began on the need to strengthen the ICFTU secretariat by increasing the number of assistant general secretaries. Most were ready to concede that it would be desirable to have additional officers with international experience, but generally affiliates were unwilling to offer the services of their own qualified staff. The CIO proposed that they, the TUC and the AFL should each appoint an assistant general secretary who would combine the role of national representative of their centre at high level meetings with administrative responsibilities in the secretariat, and together with the general secretary constitute a managing board. Such a scheme offered a means of controlling Oldenbroek, but the unorthodox combination of administrative and representative functions had no appeal for the TUC, while the AFL had no wish to see the $\mathrm{CIO}$ granted such an exalted position.

The AFL were naturally unimpressed with ICFTU performance and felt increasingly marginalized as a consequence of their exclusion from the Regional Aid Fund Committee (they were non-contributors) where the International's organizing programmes were decided. Brown characterized the ICFTU as two organizations - an official structure with a limited role and the Regional Activities Committee dominated by the TUC and acting as a state within a state. Despite the outcome at Stockholm, Oldenbroek had not changed his style, Tewson was "definitely unbearable" and the TUC were "their usual cold selves concerned with their own empire". Overall the ICFTU was a "weak, second rate organization". 19

TUC disillusionment with the ICFTU also grew, although in their case it was a product of having to bear the bulk of the financial cost of regional organizing work. Consequently in 1954 they decided to cut their financial contribution to the Regional Activities Fund and concentrate on building up their own Colonial Development Fund aimed at activities in British territories. It left the ICFTU in a dire financial situation with no guarantee of funds for organizing work beyond 1955 . What broke the log-jam was the planned merger between the AFL and the CIO. In 1955 the two organizations began to come together, and in discussion of international affairs Reuther elicited from Meany an

18 Report from Irving Brown, 24 June 1954, Meany Collection, Box 57 (23).

19 Notes on ICFTU Executive Board meeting, 1 December 1953, Meany Collection, Box 57 (22). 
acknowledgement that there were no AFL international activities that could not be performed by the ICFTU, given adequate resources. The CIO hope was that in the merged organization independent international work by each of the components would cease, being conducted in future exclusively through the ICFTU. The prospect of agreement on this enabled the two centres to join forces at the Vienna Congress in May 1955 on matters of policy, structure and finance.

What still most concerned the AFL was that the "peace offensive" of the "new look" Soviet leadership might seduce the labour movement. Although achieving little, the four-power summit at Geneva in 1955 had generated enthusiastic talk in many quarters of the "spirit of Geneva", what Lovestone chose to characterize as the "foul Geneva atmosphere". This climate had the effect of encouraging unions from different countries to exchange visits with their Yugoslav and Soviet counterparts, and to arrest this trend the American delegates at the International's Vienna Congress led the adoption of a policy against ICFTU affiliates having contacts with Soviet bloc or communist organizations. At the same time, to revitalize the ICFTU secretariat the congress decided to create a new powerful post of regional director rather than additional assistant secretaries. The person appointed would effectively be the International's number two official and as such accountable only to the Executive Board. For the AFL, it suggested a means of counterbalancing the influence of Oldenbroek. And to finance the more ambitious organizing programme that this implied, there was agreement to introduce a new levy of 1 cent per member in place of the now exhausted Regional Activities Fund.

\section{Charles Millard and the role of regional organizer}

A powerful regional director might offset Oldenbroek's influence, but the possibility that a supremo in charge of organizing might insist that all international programmes be conducted through the ICFTU was not to the liking of the FTUC and they lobbied hard within the AFL to maintain their independent programme and capacity. Irving Brown told Meany that the Americans would have no real influence if they had to rely on the ICFTU:

the extent to which we now influence policy and activities is due to our independent role and to a loyal participation in the ICFTU.

Elsewhere he argued that there was "a special role reserved to the American trade unions [... .] heightened by the special and unique role of the USA in the world today". The AFL had pioneered work in maintaining contact with underground forces behind the Iron Curtain, 
and this role was even more important now given the tendency to appeasement abroad. ${ }^{21}$

This special pleading succeeded. The capacity for independent programmes was retained in the newly merged AFL-CIO by means of a messy compromise that saw formal control of the International Affairs Department entrusted to George Brown, a Meany aide inexperienced in international affairs, while the existence of Lovestone's FTUC was quietly glossed over. In reality George Brown's appointment was a holding operation, a tacit admission that all the key decisions in this field had yet to be agreed, and the question of the direction of the International Affairs Department would remain a highly contentious matter in the years ahead.

Implementing the structural changes agreed at Vienna proved difficult, the highly political appointment of a regional director taking a full year. To ensure control of ICFTU organizing Meany wanted Irving Brown to be appointed, and there was vigorous lobbying on his behalf with informal support from the president Omer Becu. However, his nomination was resisted by Tewson and Oldenbroek and in this they spoke for many European union centres who regarded him as a confrontational personality who was likely to provoke divisions within the Confederation. The principal alternative candidate, with British and $\mathrm{CIO}$ support, was Canadian steelworkers leader, Charles Millard, who had great experience as an organizer. For several months his candidature was opposed by Meany who regarded him as a "TUC stooge". Equally his socialism (he was a former CCF provincial MP in Ontario) was a negative factor as far as the AFL-CIO president was concerned.

The struggle for the regional director's post, which saw Meany and Reuther on opposite sides, coincided with the rumbling conflict within the newly merged AFL-CIO over the direction of international policy and in particular the status of Jay Lovestone. The two issues ran in parallel for the first six months of 1956. Highly sensitive to the need to "liberate" Meany from Lovestone's mischievous influence, Reuther won backing for an AFL-CIO review of the work of the FTUC which he wanted disbanded on grounds that it was a vehicle for independent activities and that its continuation would involve further reliance on $s u b$ rosa payments from outside sources rather than a healthy recognition of the need to develop within the labour movement adequate fund-raising in support of international policy. ${ }^{2}$ From across the Atlantic the TUC watched closely as the struggle for control of AFL-CIO foreign policy took place. As much as Reuther, they wanted to see Lovestone removed,

${ }^{21}$ Brown to Meany, 19 March 1955; Irving Brown Memorandum on International Relations, 18 November 1955, Meany Collection, Box 57 (24) and Box 56 (8).

2 Victor Reuther to Walter Reuther, 6 February 1956, UAW International Department Collection (Reuther-Carliner 1956-1962), Box 83 (24). 
and Tewson informed the Foreign Office that they would be forced to take a more forthright position on the general subject of AFL-CIO international work if he remained influential. ${ }^{23}$

These two crucial issues, the appointment of the regional director and the future of the FTUC, were resolved as part of a trade-off between Meany and Reuther after several months of politicking. The approach of the 1956 presidential election season in the USA dictated the need for American labour to close ranks and in this context an agreement was reached to support Millard for regional director and to phase out after twelve months the work of the FTUC, with Lovestone transferring to the International Affairs Department and working under the supervision of its director. Irving Brown was to be catered for either by being found a post in the ICFTU (Meany hoped it would be as assistant to Millard) or returning to the USA to work in AFL-CIO headquarters.

On the surface, the compromise seemed to favour Reuther, but Meany moved quickly to damp down any impression that his position had undergone a major change. He informed Oldenbroek that these decisions by the AFL-CIO Executive Council were in the context of the need to make the ICFTU an effective agency for protecting workers from communism, an area in which the International had been deficient in the past. The termination of the independent international work of the FTUC was conditional on the regional director achieving tangible results in this field. Consequently the AFL-CIO would review the ICFTU's organizational effectiveness after one year and then decide on future programmes. ${ }^{24}$ What Reuther had understood to be agreement on a twelve-month period of notice for the FTUC had now become a twelvemonth probationary period for Millard and the ICFTU Regional Organization Department. The TUC view was that it would be impossible for Millard to achieve anything within a year and there was considerable protest at the AFL-CIO's attempt to stipulate the terms on which the ICFTU appointment was being made and approved. But in addition to this, Meany now ruled that AFL-CIO's contributions to the 1 cent fund would only begin from the date of Millard's appointment, with no retroactivity to the date of the Vienna Congress. It was a further piece of sabre-rattling and meant that Millard would be expected to begin work without the assurance of an adequate budget.

With twelve months to run before key decisions about future international work would be taken by the US labour movement, Lovestone continued to lobby on behalf of the FTUC, reminding Meany especially of the TUC's independent role within the colonies. He also made

23 Greenhough to Braine, 14 May 1956, USA Labour Attachés: Trade Unions 1955-1656, UK Ministry of Labour Papers, LAB 131218.

24 Meany to Oldenbroek and Becu, 25 June 1956, CLC Collection, vol. 257 (14). 
particular play of what he saw as a growing threat of communist influence within the TUC. Since Arthur Deakin's death the previous year Lovestone believed that there had been a lack of firm, anti-communist leadership in the TUC. Reports from the US labour attache in London had claimed that the British labour movement was sliding more and more into a neutralist position. ${ }^{25}$ For a year the WFTU had been insisting that their support among TUC members was on the rise as judged by the trend of votes cast in favour of proposed solidarity talks between the ICFTU and WFTU. Following Krushchev's secret speech to the 20th party congress earlier in the year, which suggested a growing openness in the Soviet bloc, even a staunch anti-communist like TUC International Committee chairman Charles Geddes was reported to be lining up with those in favour of union contacts with the communists. Irving Brown was doubtful whether, in this new climate, the TUC's support for the ICFTU ban on exchange visits with communist trade unions would hold if the vote were taken now. ${ }^{26}$ In such a climate, the British labour attache in Washington warned the Foreign Office of a grave possibility that George Meany might begin a campaign to whip up anti-British and anti-TUC feeling inside the American labour movement. ${ }^{27}$

Drawing these threads together in the interests of demonstrating the strategic value of the FTUC as a force for anti-communism, Lovestone wrote to Meany:

Frankly the bankruptcy of the TUC leadership as personified by the role of the pompous clerk [Tewson] is a cause for deep concern [. . . ] The frontal challenge of the Communists to guide or, at least to influence profoundly, the policies of the TUC is of the greatest concern to American labour [...] and I must not hesitate to say, to the entire international free labour movement [. . . I cannot think of a more serious blow to the ICFTU than a pollution and permeation of the TUC at a dangerous level by pro-Moscow elements in Britain. ${ }^{28}$

Contributing to the FTUC's case against total reliance on the ICFTU were Irving Brown's reports from Europe in the summer and autumn of 1956 on developments in Poland and Hungary. His urging of the International to seize the opportunity for anti-communist propaganda was thwarted in the secretariat with officials arguing for more time to assess the nature of the events in Eastern Europe. Venting his frustration with the ICFTU, he wrote to Lovestone:

23 Lovestone to Meany, 3 August 1956, Meany Collection, Box 56 (13). The labour attache, Joseph Godson, was more than a mere diplomat reporting on the British labour scene. He was part of Hugh Gaitskell's circle, a close friend of Labour Party power broker, Sam Watson, and had actually been present at Gaitskell group meetings where the proposed expulsion of Bevan from the Labour Pany had been discussed. See Carew. Labour Under the Marshall Plan, p. 129.

${ }^{26}$ Brown to Meany, 7 March 1956. Meany Collection, Box 56 (10).

27 Braine to Myrrdin-Evans, 5 October 1956, USA Labour Attaches: Trade Unions 19551956, UK Ministry of Labour Papers, LAB 131218.

2s Lovestone to Meany, 10 September 1956, Meany Collection, Box 56 (14). 
Anyone who sees this as we do over here cannot just understand how it is possible for the AFL-CIO to give up its independence in international affairs. Yes, keep [. . .] the shadow - ICFTU - but don't give up the substance, an independent American trade union policy and operation $[\ldots]^{29}$

\section{The AFL-CIO's Nine-Point Programme}

The AFL-CIO response to the dangerous developments in Europe was to issue in October 1956 a so-called Nine-Point Programme for discussion by the ICFTU Executive Board. Presented as a response to the Kremlin's "new look" strategy for advancing Soviet domination and communist influence in the world labour movement, it aimed at countering what it saw as the vastly expanded "united front" and "popular front" strategies adopted at the 20th Congress of the CP (USSR). Less than a month after Millard had taken up his post, the Americans were seeking to reassert influence over ICFTU organizing activities through the appointment of an "advisory committee" to supervise his work. Other proposals included measures to police the International's ban on exchanges of delegations with communist organizations; a stepped up campaign against colonialism, and a programme to educate labour as to the real nature of Soviet policy. Nine detailed proposals in support of these objectives were submitted to the ICFTU for formal consideration. ${ }^{30}$ It amounted to a statement of no confidence in the ICFTU's programme and leadership. However, when the Executive Board meeting considered the programme it was strongly attacked by Geddes of the TUC for attempting to undermine Millard and his programme and further discussion was postponed for six months. The Americans were furious at this outcome and Brown cabled Lovestone:

our proposal treated scandalously [...] Organization completely British controlled. Situation impossible and sterile.

"What a fiasco", he wrote later, "the ICFTU now led by Oldenbroek, Millard and Krane. How can we go on? Or should we go on?"31

The same Executive Board meeting also began to consider ambitious proposals developed by Millard to raise extra finance for organizing work through voluntary contributions to an International Solidarity Fund which would substantially supplement the existing 1 cent levy. In the prevailing climate there was little chance that the AFL-CIO would

29 Letter from Irving Brown, 8-15 September 1956, Meany Collection, Box 56 (14).

${ }^{30}$ Proposals for Action, Respectfully Submitted by the AFL-CIO to the ICFTU Executive Board meeting, November 1956, 23 October 1956, Meany Collection, Box 56 (15).

${ }^{31}$ Lovestone to Meany, 1 December 1956; Brown to Lovestone, 12 December 1956, Meany Collection, Box 56 (16). Jay Krane was Millard's assistant and a close supporter of Oldenbroek. As an American who had close contacts with the $\mathrm{ClO}$, he was deeply distrusted by Lovestone and his associates. 
support this. If nothing else, they feared that additional expenditure on Millard's organizing programme would "practically drown out anticommunist activities". ${ }^{32}$ All in all the Meany-Lovestone group now felt isolated and their bitterness towards the ICFTU leadership and the British was palpable. To Meany Lovestone wrote:

Frankly, George, such an outfit should be the last one in the world to call for solidarity funds since it does not possess elementary decency and fair play in its relations even with its own affiliates [...] If you consult your letter of October 23 to Sir Vincent Oldenbroek (sic) [Meany's letter which Lovestone had drafted to accompany the Nine-Point Programme], you will see through the whole strategy. Reckon they learned it from the crowd that scored the great "victory" over Mau Mau. ${ }^{33}$

In the wake of the Nine-Point Programme, of which he strongly disapproved, Walter Reuther made a renewed attempt to resolve the anomaly of Lovestone's role which allowed him so much influence without being on the AFL-CIO payroll or being subject to democratic control. When Reuther raised this in the AFL-CIO Executive Council in February 1957, Meany accused his closest rival for the leadership of the AFL-CIO of attempting a "hatchet job" on Lovestone and Brown and of trying to diminish his own standing around the world. He lashed out at other critics, accusing the ICFTU of being a tool of the British and repeating the charge that Millard was a British stooge. Beyond this, Meany would soon have a further catalogue of charges to make against Millard who, during his first months with the International, had publicly insisted that he was not anti-communist and was not prepared to advise affiliates against accepting invitations to meet Soviet groups. These statements were, in Brown's view, "catastrophic". "It is quite an anomaly", he wrote in his report, "to see an American-designated candidate as the champion of neutralism and what could be called 'anti anticommunism".,34 For his part Reuther informed Meany that if he continued to attack the ICFTU he, Reuther, would be forced to oppose him publicly at the forthcoming 1957 ICFTU congress in Tunis. ${ }^{35}$

The TUC shared Reuther's view that the AFL-CIO had gone too far in issuing their Nine-Point Programme and, like Reuther, they threatened

32 Brown Report on Executive Board meeting, 26-30 November 1956, Meany Collection, Box 56 (16).

${ }^{33}$ Lovestone to Meany, 1 December 1956.

34 Braine to Greenhough, 4 February 1957, USA: Trade Unions 1957, UK Ministry of Labour Papers, LAB 13 1270; Lovestone to Meany, 11 April 1957, Box 56 (19): Brown Report, 17 May 1957, Meany Collection, Box 56 (20). Millard's position here was interesting and reflected the sensitivity with which the whole question of communism in the labour movement had to be handled, especially in developing countries. As a democratic socialist, Millard had earned a reputation in the Canadian labour movement as a scourge of the communists. Yet, like Deakin and others in the British labour movement, he found the AFL's brand of anti-communism altogether too strident.

${ }^{33}$ Braine to Greenhough, 27 February 1957, USA: Trade Unions 1957, LAB 131270. 
a confrontation at the Tunis Congress if the programme were not withdrawn. A form of megaphone diplomacy between the two centres was now conducted through the columns of The Times. An unsigned article clearly informed by TUC thinking analysed internal ICFTU tensions and defended Oldenbroek's leadership while identifying Lovestone as the villain of the piece. Pointing to the TUC's loss of patience with the Americans, the article explained:

The fighting had previously been all on one side. The TUC and other organizations withdrew before every attack because until a year ago they were anxious to avoid dissension which might hamper the achievement of American trade union unity. Now that the AFL-CIO is established, they feel that they have the right to ask that all American representatives should behave as cooperative members of the international. ${ }^{36}$

TUC preparedness to defend the ICFTU against American criticisms was demonstrated very practically shortly afterwards when they committed themselves to contribute $\$ 2$ million to the International Solidarity Fund, thereby forcing the pace of Millard's new organizing drive even before the Fund had been officially established. ${ }^{37}$ For the AFL-CIO leadership it was yet another case of TUC sharp practice.

Lovestone interpreted The Times article as evidence of an international conspiracy against the AFL-CIO which involved Reuther and the British Colonial Office and whose purpose was to destroy American labour's influence in the international labour movement. Bridling at the charge that the AFL-CIO stood for "negative anti-communism", he wrote to Meany:

This is the rub. They just hate to be anti-communist [...] These people can never forget or forgive that they were fatally wrong on the WFTU issue and the AFL ALONE was right.

Equally the current British line, he claimed, reflected their resentment of the USA because of the American government role over Suez. "In no other field did the British feel strong enough to hit back against America as they did in the field of international labour, and that was because of their belief that American labour was divided and paralysed." In a reply to The Times article, Meany defiantly insisted that the AFL-CIO had no intention of withdrawing the Nine-Point Programme and, in a challenge to the TUC's international role, reminded readers that the AFL $\mathrm{CIO}$ was among the strongest advocates of a more aggressive fight against colonialism. ${ }^{38}$

36 "Discussions in Intemational Workers Organization". The Times, 18 March 1957.

37 Millard to Margo, 11 March 1957, Margot Thompson Collection 9, National Archives of Canada.

33 Lovestone to Meany, 22 March 1957, Meany Collection, Box 56 (18); George Meany, "Conflicts of Policy", The Times, 12 April 1957. 
Yet the pressure on Meany to yield was great and when, prior to the Tunis Congress, he came to assess his options the case for compromise was strong. To press forward with the nine points implied a direct challenge to the ICFTU general secretary, yet there was no credible candidate willing to stand against Oldenbroek. Urged on by Irving Brown, Omer Becu had flirted with the idea of running for general secretary and had actually announced his resignation as president to test the reaction. However, he evidently lacked confidence to challenge Oldenbroek openly and his candidature never materialized. In any event AFL-CIO hostility to the general secretary had more to do with his style and personality than his beliefs. Brown observed that Oldenbroek would go along with almost any anti-communist position that the Americans advanced, though irritatingly for them, always in a diluted form that seemed characteristic of the ICFTU's style. In terms of his policy and programme, Brown advised that Oldenbroek would not make an easy target for the Americans at Tunis.

On the other hand, Brown argued that the location of this congress in a developing African country would give extra emphasis to growing anti-colonialist sentiment in the International and that the AFL-CIO's best course would be to appear at congress as a loyal affiliate while seeking to build on the growing restiveness of Third World affiliates. ${ }^{39}$ Given this advice, Meany therefore agreed on the eve of the Tunis Congress to withdraw the Nine-Point Programme.

Tewson welcomed the move but he made it clear to Foreign Office officials that the TUC would react strongly if the anti-colonial element in the Nine-Point Programme were revived. His position was that longerterm harmony between the TUC and the AFL-CIO still depended on Lovestone being removed as adviser on international policy. Tewson saw Lovestone "as preaching Communism in reverse by the most reprehensible methods and practices of his erstwhile Communist masters". He believed that there could be no sound thinking on international matters among American trade union leaders (many of whom, he maintained, were anyway comparatively ignorant of the subject) as long as they accepted Lovestone's advice. ${ }^{+0}$

The ICFTU and anti-colonialism: 1957-1960

As Irving Brown had anticipated, the Tunis Congress in July 1957 did indeed reflect a rising tide of anti-colonialism among the union centres in developing countries. Britain was the target of much of the criticism,

30 Irving Brown Report, 17 May 1957; Brown to Meany, 18 May 1957, Meany Collection, Boxes 57 (25) and $56(20)$.

${ }^{40}$ Greenhough 10 Wilson and Treganowan, 20 June 1957, USA: Proposed Contacts, UK Ministry of Labour Papers, LAB 131271. 
and the TUC vainly tried to defend the record while the American delegates encouraged the mood of rebellion. At an African-Asian caucus meeting during the congress many delegates appealed to the Americans for assistance in dealing with the colonial powers, requested exchange visits with the Americans or US sponsored training for their union officers. ${ }^{41}$ It provided a perfect opening for the AFL-CIO leadership to promote further independent activity in developing countries. As far back as 1952, during their boycott of ICFTU bodies, the AFL had been signalling their support for nationalist movements. Now the AFL-CIO were about to take a significant initiative in Africa which Lovestone regarded as the "next field of the big test of strength" between the superpowers. ${ }^{42}$ The previous year the AFL-CIO had made an important investment in African trade unionism by donating $\$ 35,000$ towards the cost of a headquarters building for Tom Mboya's Kenyan Federation of Labour. This instance of bilateral support breached the ICFTU policy that international aid should be rendered through the International and it was privately condemned by the Confederation leadership. However, the gift cemented Mboya's loyalty to the Americans, and that would be a significant factor in African labour politics in the years ahead. ${ }^{43}$

Under Millard's direction the ICFTU was already moving towards the creation of an African Regional Organization to galvanize the Confederation's work in the continent. Speaking from long experience of African labour affairs, the TUC view was that this was premature: African unions were far too weak to sustain elaborate coordinating structures, requiring instead patient nurturing by unions from the mother country. In contrast, Irving Brown's reaction was that given the growth of communist activity in Africa the planned Regional Organization might already be too late. In January 1957 the first ever African Regional Conference had been held in the former British territory of Ghana. Much to TUC concern, a strong fraternal delegation from the AFL-CIO had attended, though without official invitation. Following the conference one of their delegates, Maida Springer, had travelled on to Tanganyika and was reported to have offered financial assistance to the country's labour movement. ${ }^{44}$

1 ICFTU Tunis Congress, Bulletins nos 4-5 \& 8, 6 and 10 July 1957.

42 Lovestone to Meany, 5 April 1957, Meany Collection, Box 56 (19).

43 Tom Mboya had assumed the leadership of the Kenyan labour movement in 1953 aged 23. By 1956, following a year's leave to study at Ruskin College, Oxford, he had gained an impressive reputation in the international labour movement. As his relationship with the British labour movement and government became more prickly, he was wooed by the American labour movement. In 1957 he became the first African elected to the Kenyan legislature and thereafter combined his trade union and political roles. As a leading figure in the Pan-African movement, he led the Kenyan delegation at the independence conference with the British government in 1960 and in 1962 became Minister of Labour in Kenya's first independent government. He was assassinated in 1969.

4 Treganowan to Greenhough, 22 May 1957, USA Proposed Contacts, UK Ministry of Labour Papers, LAB 131271. 
The new American trade union interest in Africa was given a stamp of government approval by the Eisenhower administration following a tour of the continent by Vice-President Richard Nixon in March 1957. His subsequent report recommended that America raise its profile in Africa, with greater attention paid to the condition of African trade unionism. Irving Brown now repeated the old FTUC theme: "The ICFTU cannot and will not do what American labour can and must do in the present world struggle. This means also that the Eisenhower doctrine in the Middle East and Africa must be implemented by a labour policy and personnel.",45

Against this background the AFL-CIO wasted no time in following up the opening that had appeared at Tunis. Within weeks the AFL-CIO Executive Council had agreed to appropriate $\$ 50,000$ for a programme to train African labour leaders in the United States. American fraternal delegates to the TUC conference in September 1957 were to consult on this with ICFTU leaders while in London, but this was a perfunctory gesture: the programme would begin with or without the International's blessing. Tewson and Oldenbroek told the AFL-CIO delegates that they did not like the scheme and outlined instead Millard's plan for ICFTUrun trade union colleges in Africa. The general understanding of those present seems to have been that Millard would now prepare a memorandum on a joint programme of activities for Africa, though he recognized that the TUC's own independent role in the British Commonwealth territories complicated the issue for the ICFTU. ${ }^{46}$

However, the sequel to the consultative meeting in London came as a surprise to all involved. Meany immediately assigned Maida Springer to return to Africa to launch the American training programme, and within a month she had embarked on the African programme without further consultation with the ICFTU. Her task was to spend nine months in Africa and select up to a dozen candidates for trade union training in the USA. Her visit caused consternation in British government and TUC circles. The government were worried that under closer observation the British record of colonial administration would be viewed negatively and feared the prospect of robust American anti-colonialism stoking the fires of African nationalism. The Colonial Office and the TUC were at one in wanting to maintain control of the labour situation in colonial territories, isolating it from wider political and nationalist ferment, and seeking to guide the development of trade unions and the evolution of industrial relations along approved lines. ${ }^{47}$

45 Report to the President on the Vice-President's Visit to Africa, 5 April 1957, FRUS, XV111 (1989), pp. 57-66; Irving Brown Report, 17 May 1957.

${ }_{46}$ Oldenbroek to Millard, 16 September -1957, JHO Personal 0/12, ICFTU Archives; Marsh to Greenhough, 11 September 1957, USA: Trade Unions 1957, UK Ministry of Labour Papers, LAB 131270.

${ }^{7}$ Morgan to Wilson, 13 December 1957, USA: Trade Unions 1957, UK Ministry of Labour Papers, LAB 131270. 
Springer's base was to be in Tanganyika where there was already labour unrest and union opposition to restrictive British colonial labour legislation. Believing that she would foster agitation over the legislation, the colonial authorities kept her under close surveillance and there was serious discussion in government circles of refusing to renew her visitor's permit and even expelling her. Noting her meetings with Julius Nyrere, Tom Mboya and others, the Secretary of State for Colonial Affairs was "afraid she may be assuming the role of geopolitical go-between among African nationalist leaders in East Africa and even beyond". 48

To defuse a situation that threatened to be diplomatically damaging, Walter Reuther secured Meany's agreement to invite Oldenbroek and Tewson to the AFL-CIO convention in Atlantic City in December 1957 for what would be a resumption of the consultations that had been held in London. At the same time, he urged Millard to develop concrete ICFTU plans for organizing and training in Africa.

The Atlantic City meeting surprised most people by producing an agreement that seemed to offer the prospect of international labour peace and cooperation within the ICFTU. The independent African programme of the AFL-CIO was to cease immediately, with the remainder of the earmarked funds channelled through the ICFTU for use in setting up an African training college. The AFL-CIO leaders finally agreed to support the International Solidarity Fund and promised to seek their Executive Council's authorization to donate $\$ 1 \mathrm{~m}$. In addition, the Americans agreed to discontinue the work of the FTUC, with Lovestone to be transferred from his independent base in New York to Washington and finally brought under the control of the International Affairs Department. ${ }^{49}$

On the surface it seemed again that Meany had been obliged to make major concessions, but the reality was rather different. The Americans had forced an entry into Africa and would now have to be involved in ICFTU work there. The AFL-CIO Executive Council resolved to wage an all-out campaign against colonialism in that continent, and Meany's pressure on Oldenbroek to engage Americans on the African programme was unremitting. Moreover the concessions concerning the FTUC were no more than a tactical retreat and, as such, of little concern to Lovestone. As he told a colleague:

I shall be continuing all the work I did under the new title. Please note there is no announcement of any dissolution of the Free Trade Union Committee. It can always be brought back since it was never dissolved [....] under the label of the FTUC, all vital and effective international activities were conducted.

4 Secretary of State for Colonial Affairs to Twining, 12 November 1957, USA Proposed Contacts, UK Ministry of Labour Papers, LAB 131271.

* Irving Brown Report, 2-4 March 1958, Meany Collection, Box 57 (1); Millard to Margo, 1 January 1958, Margot Thompson Collection 12. 
And later in the same vein:

I have been buried many times and I've had my carcase picked at. There will be many a vulture forced down before getting at me. I take a special delight in strangling vultures before they get to me. That is one of the reasons for my office in Washington. ${ }^{50}$

The ICFTU plan was to establish a training college in Kampala, capital of the British territory of Uganda. However, for the first time a major public disagreement now emerged between the International and the TUC. At a meeting with the TUC's International Committee in February 1958, Oldenbroek and Millard called into question the TUC's own private programme in the African colonies. It was a heated meeting after which TUC representatives began to talk of withholding contributions to the International Solidarity Fund. Disenchantment with the ICFTU began also to affect the British government. Over the years they had always encouraged the International by being helpful with visas for visitors to British territories, but government officials now wondered whether the ICFTU was worth the trouble. Irving Brown interpreted this sudden souring of relations as "the biggest and decisive turning point in the international labour movement". 51 To Meany and his associates the TUC and ICFTU leaderships had always appeared as one. Now vocal AFL-CIO opposition to colonialism in Africa was forcing them apart.

Increasingly regional director Charles Millard saw the TUC as the main obstacle to ICFTU harmony. He had never received much assistance from the Americans, but now frustration with the TUC led him to consider resignation. His biggest disappointment, he told colleagues, was Tewson and the TUC: "Personally, I cannot and will not accept the 'double standard' concept [. . . ] the refusal to apply self-discipline or to give up a tiny bit of autonomy will eventually rob the ICFTU of any real meaning or importance." The TUC made no secret of their concern that the Kampala college would establish a vehicle for Americans "prancing around in Africa", 52 and Millard was depressed by "the knowledge that neither Tewson nor the TUC are prepared to live by the same rules that they have asked Meany. and Randolph to accept at Atlantic City".33

so Lovestone to Deverall, 12 and 31 December 1957, Victor Reuther Collection, Box 31 (7).

st Irving Brown Report, 1 March 1958, Meany Collection, Box 57 (1): "Relations Between TUC and AFL-CIO", undated, USA: Trade Unions 1958, UK Ministry of Labour Papers, LAB 131324.

52 Notes by Walter Hood, 29 April 1958, ICFTU 1958-1960, TUC Archives 292 919.66/2. ${ }^{53}$ Millard to Jodoin and MacDonald, 11 July 1958, CLC Archives, microfilm reel H191. A. Philip Randolph was the black leader of the Brotherhood of Sleeping Car Porters and had been centrally involved in devising the AFL-CIO training programme for Africa. He was opposed to the concessions required of the AFL-CIO in the Atlantic City accords. 
As planning for the Kampala training college went ahead, all the obstruction came from the British. Tewson maintained that given the political orientation of African labour officials, many of whom, as in the case of Mboya, were as much nationalist political leaders as union functionaries, it might not be possible to maintain the strict trade union character of the training school. In their resistance to the programme, the TUC operated in close consultation with the Colonial Office. Tewson and the Secretary of State for the Colonies met in June to consider the appropriate British position. They gave the college final approval, but with considerable reluctance. TUC support for the initiative was always grudging and the Colonial Office only tolerated the programme on the grounds that the alternatives - an African college located in Ghana where African nationalism was even more virulent, as favoured by some Americans, or even the revival of a fully-fledged independent programme by the AFL-CIO - would be worse. ${ }^{54}$

\section{The spectre of Pan-Africanism}

The outstanding African issue for the ICFTU remained the creation of the long-delayed African Regional Organization as a mechanism for trade union coordination. African union impatience was growing, and before the Regional Organization became a reality a tide of Pan-African sentiment in favour of a purely African labour federation unaffiliated to the ICFTU threatened to overtake it. At the All-African People's Conference held in Accra in December 1958 it was decided to establish an All-African Trade Union Federation, the main unresolved question being whether or not its affiliates would also be eligible to belong to the ICFTU. The prospects for the Confederation in Africa were now in considerable doubt. The presence at the conference of an AFL-CIO delegation led by Irving Brown had helped prevent an immediate decision against contacts with the ICFTU. However, the ICFTU could derive little comfort from this for, as Irving Brown reported to Lovestone:

The prestige of the ICFTU is extremely low as was demonstrated by the meeting of trade unionists held during the conference. Even those affiliated to the ICFTU were not especially keen on the work of the ICFTU in Africa [...] There is no question that this policy is one that will be continuously pursued by the communists in Africa [...]

He claimed that American labour still had a reserve of goodwill in Africa, but warned that this was being lost because of its connections with the TUC and the ICFTU and above all because of unfavourable publicity surrounding the dropping of its independent African training

34 Morgan to Wilson, 29 May 1958; Wilson to Morgan, 3 June 1958, USA Proposed Contacts, UK Ministry of Labour Papers, LAB 131271. 
programme..$^{55}$ The implication was that as long as affiliates from European colonial powers held sway in the International, its relations with African unions would suffer. Lovestone conveyed the message to Meany in more dramatic language:

Had it not been for American labour's activities in the past and the participation of the AFL-CIO representative in this Accra Conference, our country and the free world would be out in the cold here entirely and the movement towards African freedom would by now have been completely in Moscow's grip. As it is, we still have a good chance. It is clear that the help which you once gave to Tom Mboya and the Kenya Federation of Labour has been more than rewarded in deed. ${ }^{36}$.

Meany duly renewed an offer to Oldenbroek to send black American labour staff to Africa to help stem "the anti-ICFTU tide", but Oldenbroek declined the offer and spoke complacently of the ICFTU's "remarkable progress" in the continent. Totally dissatisfied with this response the AFL-CIO Executive Council proceeded to call on the American government to urge the rapid granting of independence to African countries; the establishment of economic and technical assistance programmes by the US government; and a strengthening of American diplomatic missions in Africa. In the meantime it pledged itself to assemble a team of labour officials who would be willing to go to Africa as part of an American programme. ${ }^{57}$

Vincent Tewson was incensed at this move by the AFL-CIO and the TUC now issued a lengthy analysis of African labour developments that was highly critical of African union leadership, American intervention and the ICFTU's own role. Trade union centres such as the Kenya Federation of Labour were portrayed as undemocratic, prone to totalitarian tendencies and subject to outside manipulation. Some of the responsibility for this lay with the ICFTU which had artificially built up the leadership and created a situation of "licensed corruption". Other factors at work were the communist strands in Pan-African thinking with its American and West Indian roots. "Black racialism" was growing within the ranks of African labour, and the British maintained that both the AFL-CIO and the ICFTU had encouraged it. The TUC rejected the view that there was a distinct form of trade unionism in Africa that justified the establishment by the International of an African Regional Organization. Such a structure would be an artificial creation and expensive to operate. The document went as far as to argue that African union centres were not fit to be ICFTU affiliates.

ss Report on All-African People's Congress, 5-14 December 1958; letter from Irving Brown, 16 December 1958, Meany Collection, Box 57 (26) and (3).

${ }^{36}$ Lovestone to Meany, 22 December 1958, Meany Collection, Box 57 (3).

57 Statement by the AFL-CIO Executive Council on Africa, 20 February 1959, TUC Archives 292 901/15. 
Beyond this the TUC condemned the AFL-CIO's "negative anticolonialism" because it made no contribution to trade unionism. As far as they were concerned, the most effective help to African trade unions was rendered via the government labour officers of the colonial administration. Without any sense of irony the TUC warned of the danger in Africa of domination by "outside influences". It was always central to the TUC view that they were not outsiders and that only the British understood the realities in Africa. ${ }^{58}$ If there was to be any lasting understanding between the TUC, AFL-CIO and ICFTU on Africa it would need to be an agreement on "basic principles of trade unionism" (emphasis in the original). And in immediate practical terms that would necessarily mean the Kampala College programme confining itself strictly to trade union subjects. ${ }^{59}$

\section{The campaign to remove Oldenbroek}

The ICFTU secretariat now found itself under general attack, Oldenbroek and Millard in particular the targets of American, British and impatient African criticism. In the course of 1959 the ICFTU's staunchest defender within the AFL-CIO, Walter Reuther, became steadily more critical of the International's leadership, more inclined to accept that there was some basis to Meany's hostility to Oldenbroek. What seems to have weighed particularly heavily with him was the impression he formed from discussions with Tom Mboya in spring 1959 in which the Kenyan persuaded Reuther that time was running out for the ICFTU in Africa and that if changes in personnel were not made there was a distinct possibility that African unions would desert the International and throw in their lot with the All-African Trade Union Federation.

Against this background, Reuther travelled to Europe in May 1959 for talks with European labour leaders and in the course of these the idea was first mooted that Oldenbroek should be forced to resign. Indeed there was growing talk of a "clean sweep" of the International's top level leadership. The following month, in the course of the ICFTU Executive Board meeting Meany led a three-man delegation, including the ICFTU's new president, Arne Geijer, to see Oldenbroek and told him that he did not have their confidence and that if he continued in office the AFL-CIO would reduce its involvement in the ICFTU. ${ }^{60}$ To

38 Bert Lewis, the TUC appointee on the Kampala College teaching staff, for example, wrote of the "non-British [i.e. American and Swedish] staff" of the College "not understanding African society". Undated Report on ICFTU African Labour College by Mr A.E. Lewis, c. March 1959, TUC Archives $292901 / 15$.

39 The Conception of Pan-Africanism and Other Influences Affecting Trade Union Organization in Africa, TUC, CACIC 2/1, 9 March 1959; Bowers to Woodcock, 14 April 1959. TUC Archives $292901 / 15$ and 919.662.

on Geijer to Reuther, 6 July 1959, Victor Reuther Collection, Box 26 (10). 
the dismay of his critics Oldenbroek refused to oblige and Reuther for one now believed that the upcoming Brussels Congress in December would be the last opportunity to rescue the International from its general secretary. Writing to Geijer, Reuther insisted:

we cannot continue to permit the domination of the ICFTU by the inflexible personality of Oldenbroek [...] the people of Asia, Africa and Latin America who are on the march will not wait nor adjust their time schedule to accommodate $\mathrm{Mr}$ Oldenbroek's inflexible attitude [. . . If we do not act at the December Congress, then we might forfeit our opportunity. History will not wait. ${ }^{61}$

Omer Becu was still the American choice to replace Oldenbroek as general secretary but at the Brussels Congress in December he was unwilling to be nominated unless Oldenbroek stood down, and again the general secretary refused to do so. With no progress in resolving the leadership question, the congress made little headway and was widely regarded as the least harmonious of all ICFTU gatherings. Meany spoke out against Western colonialism which was "morally wrong and politically destructive", making clear American determination to help workers in newly independent countries despite the "dead hand" of ICFTU bureaucracy. TUC delegates defended the record, referred to the problem of inadequate ICFTU funding and reproached the AFL-CIO for preaching anti-communism to empty bellies in developing countries. ${ }^{62}$

Unable to resolve immediately the leadership question, the congress played for time and appointed an Ad Hoc Committee to review the future structure of the Confederation. In effect it was a device to negotiate Oldenbroek's resignation and secure Becu's agreement to replace him. A majority of large affiliates were now prepared to sacrifice the general secretary in the interests of harmony or simply to appease the Americans. Vincent Tewson remained part of a dwindling number who were prepared to support Oldenbroek. Within the Ad Hoc Committee he maintained a rearguard action throughout the first half of 1960 in defence of his old colleague, before finally being forced to accept defeat.

Eventually, in June at a closed meeting of the ICFTU Executive Board, with no delegate from a large affiliate willing to speak in his favour, and other delegates either voicing no confidence or simply resigned to the fact that the Americans were determined to have their way, Oldenbroek was isolated. Meany announced that if the ICFTU were reorganized "all activities of the AFL-CIO in the overseas field [would] be conducted through the International Solidarity Fund and the regular machinery of the ICFTU". At this Oldenbroek agreed to resign. In a final statement, he pointed out that he had never had the wherewithal to do a proper job and that the organization would never be any

61 Reuther to Geijer, 22 July 1959, Victor Reuther Collection, Box 26 (11).

62 The Times, 7 December 1959. 
good unless it had the complete cooperation of all affiliates. Alluding to the practice of national union centres buying the support of Third World movements, he declared that the ICFTU was involved in a great fight - bigger than that against communism - "the fight against corruption which challenges our movement". ${ }^{3}$

Becu, the American choice and former ICFTU president, was offered the general secretaryship and took up the post in August. Immediately he set about drafting a programme emphasizing devolution within the ICFTU. The International leadership would allocate budgets, while leaving considerable leeway to regional organizations in deciding on particular expenditures within the global figure. Within this framework there would be a relaxed approach to independent initiatives by national centres. It was a formula designed to appeal particularly to the Americans. The proposals were strongly criticized by Millard and his Organization Department staff who argued the case for greater centralization of authority in order to overcome national rivalry and criticized the proposals for being cast in institutional terms whereas the key relations were human relations. Only if there were mutual trust and confidence would relations between the secretariat and the regions function smoothly. ${ }^{64}$ However, Millard's opinions counted for little with Becu who planned anyway to eliminate the post of regional organizer.

Becu was much more cautious in matters of personnel. Predictably the AFL-CIO sought a position of influence for Irving Brown within the International, though they recognized that this would be strongly resisted in many quarters. Prior to Becu's appointment there had been an unwritten understanding between him and Meany under which the Americans would refrain from pressing the case for Irving Brown to be appointed assistant general secretary so long as Becu would work closely with Brown and make full use of his ability. ${ }^{65}$ But once in office the new general secretary was very careful to keep Brown at arm's length and the latter protested to Lovestone: "I refuse to be put in a position any more of merely being on the periphery or appearing as an outsider in the eyes of the general secretary of the ICFTU [....."

When the Executive Board convened for the first time with Becu as general secretary in late November it was clear that his honeymoon period was already over. Meany took him to task, telling him publicly that he had been given a job to do and had failed to do it. The AFL-CIO president had arrived in Brussels authorized to pay $\$ 230,000$,

63 Irving Brown Report on Closed Session of ICFTU Executive Board, 28 June 1960 , Meany Collection, Box 58 (2).

* Millard to Becu, 21 October 1960, Jay Krane Collection, Box 17 (34), Walter Reuther Archives.

6s Krane to Victor Reuther, 10 December 1960, UAW International Department Collection (Reuther-Carliner 1956-1962), Box 123 (13).

* Brown to Ross and Lovestone, 14 November 1960, Meany Collection, Box 58 (2). 
the outstanding balance of a sum owing to the ICFTU. He produced a cheque but then refused to hand it over on grounds of dissatisfaction with Becu's performance in the three months since taking over as general secretary. ${ }^{67}$

The Executive Board meeting reached a climax with a formal dinner held to honour the retiring general secretary. Friendly tributes were being paid to Oldenbroek when Meany insisted on making an unscheduled speech in which he attacked the new leadership and admitted to having made a mistake in his choice of general secretary. On his return to the United States, Meany denounced the ICFTU as a "cesspool". Becu had now been fully alerted as to the battlefield that he was entering. For him relations with the AFL-CIO would scarcely be any easier than they had been for his predecessor. ${ }^{68}$

\section{Conclusion}

After a decade of struggle to establish itself, the ICFTU's future looked far from promising at the start of the 1960 s and there were observers who wondered seriously whether the organization would survive. Certainly among Lovestone watchers some speculated that the chief architect of AFL-CIO international policy would rather wreck the ICFTU than see it controlled by his opponents.

At issue was the problem that had frequently divided labour movements in the past - a basic conflict over the essential nature of trade unionism and its relationship to politics. The WFTU had split over this, the tensions created by the offer of Marshall Aid highlighting the difficulty of reconciling the Leninist model of trade unionism as adapted to Stalinist totalitarianism. with the practice of trade unionism under Western capitalism. Within the ICFTU, the competing positions were far less polarized, but the issue of what "free" trade unionism meant and the correct response to the challenge of communism were sufficiently contentious to drive apart even labour centres that shared many common values. The TUC and the AFL had a unique fraternal relationship extending back to the nineteenth century. They had more in common with one another than with many other ICFTU affiliates, sharing language, some cultural characteristics and a pragmatic approach to trade unionism rooted historically in craft organization. The difficulty of creating harmony even between such partners boded ill for the future of labour internationalism.

The significance of the ensuing deadlock was that it undermined the authority of labour's voice in international affairs, diminishing the

67 Krane to Victor Reuther, 10 December 1960.

68 Millard to Eileen and Bert, 29 November-3 December 1960, Margot Thompson Collection 23; Personal Notes Dictated by Walter Reuther, 8 March 1961, Victor Reuther Collection, Box 31 (11). 
standing of the organization that sought, on behalf of the largest group of organized workers in the non-communist world, to represent the values of trade unionism to the international community at large. Indeed, within the world of labour, discord inside the ICFTU hampered attempts to project an international value system that might have appealed to the better instincts of trade union members generally.

As a matter of routine, politics took precedence over practical trade unionism. Inside Lovestone's circle virtually no thought was given.to the question of how to organize worker solidarity for economic and social betterment. The forging of links between the ICFTU and NATO or the sponsoring of covert activities against Eastern bloc countries were considered more important than developing a trade union consciousness among workers and the rudiments of how to organize against employers, let alone how to deploy such solidarity on the international stage. Irving Brown's opposition to Millard's proposed International Solidarity Fund for basic organizing work among labour in developing countries was, after all, that it would "drown out anti-communist propaganda". As the TUC complained, for geopolitical reasons the Americans were inclined to afford support and recognition to embryonic trade union centres before they had developed an organizational infrastructure or the capacity to confront employers at local level. In contrast, the TUC's instinct was to help build trade unions in developing countries from the base up. However, the problem with their approach was the expectation that the organization in question must reflect the British model of nineteenth-century trade union development, evolving slowly upwards from a local base. The seeming lack of urgency in this approach, combined with British reluctance to accord full status to national labour centres in former colonial territories, thus resulted in the TUC too being cast in the role of colonial manipulators.

Amidst this internal struggle for dominance, the Confederation was starved of funds and resources and frustrated in its attempt to give a concerted lead in implementing a range of international policies. Competing with ICFTU programmes were a series of partial projects conceived or operated independently by individual affiliates. Instead of genuine internationalism promoted by a supra-national labour confederation there were, all too often, limited international interventions by independent national centres, operating at times in direct competition with a rival independent programme, each sponsoring body in pursuit of its own national self-interest. And as Oldenbroek warned in his resignation speech, the corrosive effect of such independently financed initiatives was that they would lead to the competitive purchasing of support of developing labour movements by one or another of the big powers.

The factor that drove a wedge between the British and American trade unions was, of course, the cold war and their different responses to the challenge of communism. A certain amount of mutual mistrust 
had existed even at the foundation of the ICFTU. Their relationship during the previous four years had been uneasy as a result of the existence of the WFTU. The TUC had helped found that body and supplied the president in the person of Arthur Deakin. Despite some misgivings about the politics of the WFTU, the TUC worked within it as a loyal affiliate until the pressures associated with Marshall Aid led them to withdraw. On the other hand, the AFL never belonged to the WFTU, refused any association with trade union centres from the Soviet bloc, and from the outset worked hard for the break-up of the Federation. In all this the TUC carefully maintained its distance from the AFL and resisted being drawn into anti-WFTU intrigue. The lack of trust that this reflected on the part of the TUC was matched by the AFL perception that the British were perhaps not the most reliable of allies in the battle against communism. That perception continued throughout the 1950s.

The curious characterization of the TUC leadership as soft on communism reflected only the more extreme position of the AFL. Lovestoneism provided the yardstick, and under Lovestone's influence anti-communism was taken by the AFL to be the overriding purpose of "free" trade union organization. Yet to the TUC leadership and many in the CIO, the challenge posed by communism was simply part of the context in which basic economic trade union activity took place. In principle, there was no capitulation to communism by them, but there was a pragmatic acceptance, which grew stronger as the decade progressed, that occasional compromises were essential.

Whereas for the AFL, trade unions were organizations through which an explicit.ideological struggle had to be waged, the TUC approach was that practical trade unionism built patiently from the bottom up would best serve the material interests of -workers and, in the process, lessen the appeal of communism. However, the idea implicit in this, that communism's chief appeal was to the hungry - the theory of "belly communism" as Lovestone called it - was rejected by the FTUC for its complacency. The threat of communism was much more urgent than that and had to be fought in other ways.

The differences over how to respond to communism later fed into their disagreement over African trade union affairs. There the Americans were concerned that colonialism would breed a communist backlash, whereas the TUC felt confident that there was little threat from communism in Africa. On the other hand, the TUC did see nationalism as a significant problem and a threat to real trade union development. In their haste to build grand trade union structures in Africa, the TUC accused the AFL-CIO and the ICFTU of concentrating on central union federations led by African nationalist politicians, rather than constructing the essential building blocks of a sound labour movement from the base upwards. 
Over the decade, these divergent perceptions were exacerbated by matters of style and tone. The Americans were restless, energetic, brash and forceful and, the TUC would say, often naive. The British were staid, methodical, reserved and, in the eyes of many American counterparts, insufferably smug and superior. All of these factors were imported into the ICFTU and became part of its politics. The AFL soon concluded that the International which they had worked so hard to establish and shape was effectively under British control. The Dutch general secretary, Oldenbroek, was an anglophile who had spent much of his working life in London and was philosophically and temperamentally on the same wavelength as TUC general secretary Tewson. Unflappable and able to rise above passing crises, Oldenbroek's long-term view was that the ICFTU had very much the upper hand over the WFTU. However, the Americans saw the secretariat that Oldenbroek presided over as staffed largely by Europeans whose politics were assumed to be socialist or social democratic and whose purpose was not trusted. The TUC never felt the same mistrust of the ICFTU head office that the AFL-CIO did.

Contributing to the lack of harmony in the International was the physical problem experienced by the AFL-CIO of participating in meetings for the most part held in Europe. Senior American union leaders were often unable to attend routine Executive Board meetings and it was felt that the AFL-CIO failed to punch its weight in this forum. Instead they had to be represented by Irving Brown, an extremely capable and well-informed person, but a man lacking the prestige of elected office and one who made enemies easily and was widely regarded in Europe as an abrasive factionalist and personal representative of Jay Lovestone. There seems little doubt that Brown's permanent presence in Europe and the personal vendettas in which he was caught up contributed significantly to the strained atmosphere in the ICFTU.

It is arguable that the Americans contributed to their own difficulties in the International through their successive financial boycotts of organizing programmes. "No representation without taxation" was the operating principle in the ICFTU, and the result was that the AFL and later the AFL-CIO found themselves marginalized in decision-making over organizational activities, with the TUC's voice in relative terms that much stronger. The overall effect, though, was that the ICFTU was under-resourced and criticisms of its lack of achievement were, therefore, to some extent self-fulfilling.

Ultimately, of course, the problem was that neither the TUC nor the AFL-CIO ever placed total reliance on the International. In both centres there was an ambivalence about the ICFTU - rather more pronounced in the case of the Americans - under which their instinct was to participate in the International so as to prevent it adopting wrong-headed policies in areas of strategic national interest, while taking independent initiatives where such interests suggested that this was the most 
appropriate course. Indeed, independent activities were often the rule rather than the exception, and internationalism pursued through the International was less common than idealists would have wished. Thus for most of the 1950s the TUC could rest content in the knowledge that the Confederation under Oldenbroek would pursue no policy harmful to TUC interests, early ICFTU programmes in Africa being conducted with substantial guidance from the British. It was only when the AFL-CIO established an interest in Africa in 1957 and encouraged the ICFTU to adopt a more dynamic approach to the continent that the TUC began to regard the International's presence as unwelcome. Having criticized the Americans' "negative anti-communism" for much of the decade, the TUC now sought to defend its own independent programme by attacking their "negative anti-colonialism". Each failing to develop a consistently unselfish international perspective, these two leading affiliates were unable to give the ICFTU a coherent policy lead. As a consequence, at the end of its first decade the Confederation's long-term survival was by no means assured. 